\title{
亜鉛-臭素電池のシャント電流解析と電池構成
}

\begin{tabular}{|c|c|c|c|c|c|}
\hline 正 員 & 金 & 成 & 克 & 彦 & (電総研) \\
\hline 員 & 野 & 崎 & & 健 & (電総研) \\
\hline 員 & 神 & 本 & 正 & 行 & (電総研) \\
\hline & 橋 & 本 & 敬 & & (明電舎) \\
\hline & 藤 & 井 & 利 & 宣 & (明電舎) \\
\hline
\end{tabular}

\section{Charge and Discharge Simulation of Zinc/Bromine Batteries for Various Battery Configurations}

Katsuhiko Kanari, Member, Ken Nozaki, Member, Masayuki Kamimoto, Member (ETL), Takahumi Hashimoto, Non-member, Toshinobu Fujii, Member (Meidensha Corp.)

Zinc/bromine batteries were developed by Meidensha Corporation for load leveling under the "Moon Light Project" by Ministry of International Trade and Industry (MITI). One of problems in the bipolar cell assembly of zinc/bromine batteries is shunt current loss which causes not only a decrease in electrical efficiencies but also non-uniform zinc metal deposition. Computer simulations based on an equivalent circuit model were carried out for estimation of charge and discharge characteristics of a string of the $1 \mathrm{MW}$ scale zinc/bromine batteries. The round-trip efficiencies, the residual zinc metal after discharge, the stack currents and the terminal voltage were estimated. The effects of battery configurations and the fluctuation of cell parameters on charge and discharge characteristics are discussed.

キーワード：亜鉛-臭素電池，電池構成，シャント電流，等価回路，重鉛電析分布，充放電効率

\section{1.まえがき}

亜鉛一臭素電池は, 臭化亜鉛の水溶液 (電解液) を 用いたエネルギー密度の高い二次電池であり(1), 電解 液は電解槽の外のタンクに貯蔵し, 必要なときに電解 槽に循環供給して充放電させる。このため, 電池出力 とは独立に貯蔵容量を増やすことができる，電解液の 管理が容易である，などの特徴を電池にもたせること ができる(2)。これらの特徵を生かして, フロー型の严 鉛一臭素電池が電力貯蔵用二次電池 ${ }^{(3)}(7)$ および電気自 動車用二次電池 ${ }^{(8) \sim 10)}$ として開発されている。

本電池の単電池の起電力はたかたか $1.7 〜 1.9 \mathrm{Vで}$ あるのて，実用的な電圧を得るため多数の单電池を心゙ イポーラ直列接続してスタックを組み立て,このス夕 ックの直並列接続により電池を構成する必要がある。
ムーンライト計画のもとに開発が進められた $1 \mathrm{MW}$ 級亜鉛一臭素電池ストリング(5)(6) では，後で述べるよ うに, $30 \times 24 \times 24$ 個の単電池の直並列接続に上り棈 成されている。充放電時, スタック内の各単電池に導 電性の電解液 (正負極液) を並列に供給するので, この電解液を通してシャント電流が流れ, 充放電効率 の低下(1) の一因となる。

西鉛-臭素電池の主要な課題の一つが，亜鉛電析に 関連する問題であるが(1)，上記のシャント電流はス夕 ック内の単電池当たりの亜鉛電析・溶解量の分布の一 因となる ${ }^{(12)}$ 。更に, 電池を構成する単電池やス夕ッ クなどの充放電特性にばらつきがあると, 各要素の充 放電電流上残留亚鉛量のばらつきが生ずるので，電池 性能や信頼性の低下の原因となる。

垔鉛一臭素電池のモデリング，効率推定などのため， 
単電池内の活物質の対流, 拡散, 電気化学反応などを 取り扱ったモデル(13)，簡便な式による効率の推定 ${ }^{(14)}$, 等価回路を用いる方法(11) などが報告されている。し かし, 単電池内のイオン移動, 反応を表すモデル(13) は複雑すぎて, 多数の単電池が直並列に接続された電 池への適用が困難である。また，簡便な式を用いる方 法 ${ }^{(14)}$ やシャント電流コントロールのための解析法 ${ }^{(11)}$ では，充放電時に各単電池の負極で垔鉛が電析・溶解 する問題を取り扱っていない。

著者らはこれまで、レドックスフロー型電池の等価

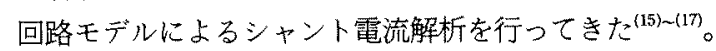
このモデルをもとに，亜鉛-臭素電池のための等価回 路モデル作成し，1 $050 \mathrm{~kW}$ 級電池 ${ }^{(3)(4)}$ に適用し た。充放電電圧, 充放電効率を推定した結果, 実駼結 果とよい一致を得てスタックのための等価回路モデル を確立した ${ }^{(18)(19) 。}$

本研究では，亜鉛一臭素電池の電池構成と電池の充 放電特性との関係を明らかにするため，スタックのた め等価回路モデル(18)(19) をもとに, 電力貯蔵用新型 電池の一つとして開発が進められた $1 \mathrm{MW}$ 級亜鉛一臭 素電池ストリング(5)(6) を対象に等価回路モデルを作成 し，充放電シミュレーションを行った。ストリングの 充放電電圧や充放電効率へのスタック直並列接続法や スタック特性ばらつきの影響を検討した。

\section{2. シャント電流解析}

\section{〈2・1〉1 MW 級垔鉛-臭素電池の電池構成}

電力貯藏用に開発が進められた亜鉛臬素電池は，1 $\mathrm{kW}$ 級から $50 \mathrm{~kW}$ 級にスケールアップされ(3)(4), 最終 的には，1 MW 級の規模で実証試験が行われた ${ }^{(5)(6)}$ 。 それぞれの電池の仕様を表 $1^{(3) \sim 6)}$ に示す。

図 1 に $1 \mathrm{MW}$ 級要鉛-臭素電池ストリング(5)(6) の電 池構成の一例を示す。30セル (単電池) の直列接続 により $1 \mathrm{~kW}$ 級スタック（図2）が，24 個のスタック の並列接続により $25 \mathrm{~kW}$ 級サブモジュールが，24 基 のサブモジュールの直列接続により $1 \mathrm{MW}$ 級ストり ングが構成される。

図1に示したように，ストリングに直列接続されて いる各サブモジュールには, 正負極液用のタンクが付 属されている。各タンクからの正負極液は, 並列に接続 されている各スタックに供給され，更に図2に示すよ うに, スタック中に直列接続されている各単電池に マニホールドやスリットを通して並列供給される。

上記のような電池の設計上のポイントは，（i 各サ ブモジュールに付属されているタンク内の電解液量と 電解液中の活物質の初期濃度, (ii) 上記のタンク内の
表 1 亜鉛-臭素電池の仕様(3) (6)

Table 1. Specifications of $z$ inc/bromine batteiries $^{(3) \sim(6)}$.

\begin{tabular}{l|lll}
\hline Item & \multicolumn{3}{|c}{} \\
\hline Rated output & $1 \mathrm{~kW}$ & $50 \mathrm{~kW}$ & $1 \mathrm{MW}$ \\
Capacity & $8 \mathrm{kWh}$ & $400 \mathrm{kWh}$ & $4 \sim 8 \mathrm{MWh}$ \\
Electrode area & $800 \mathrm{~cm}^{2}$ & $1,600 \mathrm{~cm}^{2}$ & $1,600 \mathrm{~cm}^{2}$ \\
Neg.and Pos.electrolytes & $3 \mathrm{M}^{\mathrm{a}} \mathrm{ZnBr}_{2}+2 \mathrm{M} \mathrm{NH}, \mathrm{Cl}+\mathrm{QBr}$ \\
Current density & $12 \mathrm{~mA} / \mathrm{cm}^{2}$ & $13 \mathrm{~mA} / \mathrm{cm}^{2}$ & $13 \mathrm{~mA} / \mathrm{cm}^{2}$ \\
Duration of charge & $8 \mathrm{~h}$ & $8 \mathrm{~h}$ & $4 \mathrm{~h} \sim 8 \mathrm{~h}$ \\
Duration of discharge & $4 \mathrm{~h} \sim 8 \mathrm{~h}$ & $6 \mathrm{~h} \sim 8 \mathrm{~h}$ & $4 \mathrm{~h} \sim 8 \mathrm{~h}$ \\
Number of cells $)^{\mathrm{c}) \text { d) }}$ & $16 \mathrm{~s}$ & $30 \mathrm{~s}$ & $30 \mathrm{~s}$ \\
Number of stack & $4 \mathrm{p}$ & $24 \mathrm{p}$ & $24 \mathrm{p}$ \\
Number of submodules & & $2 \mathrm{~s}$ & $24 \mathrm{~s}$ \\
Open circuit voltage & $1.8 \mathrm{~V}$ & $1.8 \mathrm{~V}$ & $1.8 \mathrm{~V}$ \\
\hline
\end{tabular}

a) $\mathrm{M}: \mathrm{mol} / \mathrm{dm}^{3}$, b) Bromine complex reagent, c) s: Series, p: Paral. lel, d) in a stack

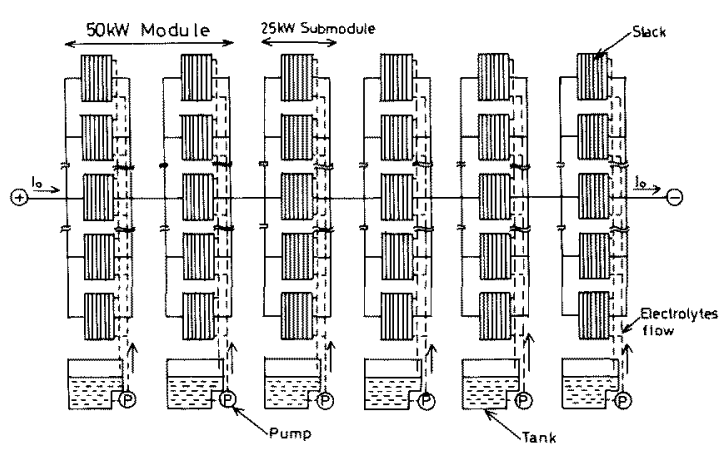

図 $11 \mathrm{MW}$ 級亚鉛-臭素電池ストリングの 電池構成

Fig. 1. Configuration of a string of the $1 \mathrm{MW}$ scale zinc/bromine battery.

電解液量と電解液中の活物質の初期濃度のばらつき, (iii)スタック内単電池直列接続とサブモジュールの直 列接続数, (iv) 単電池の電極面積, 充放電電流密度, サブモジュール内のスタック並列接続数，(v)スタッ ク内の単電池の充放電効率, 内部抵抗のばらつき, (vi)サブモジュール内の各スタックの充放電効率, 内 部抵抗のばらつきなどである。

〈2・2〉モデルおよび仮定図 2 の垔鉛一臭素電池

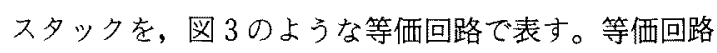
は, 单電池の開路電圧 $\left(E_{0}\right)$ と内部抵抗 $\left(R_{c}\right)$, スリ ット抵抗 $\left(R_{s}\right)$, マニホールド抵抗 $\left(R_{m}\right)$ の回路要 素から構成される。なお，図 3 中の $R_{c 1}$ と $R_{\mathrm{c} 2}$ および $E_{01}$ と $E_{02}$ の和は，それぞれ， $R_{c}$ と $E_{0}$ である。更 に, 図 3 のスタックの等価回路の直並列接続により, 図1のストリングを図 4 のような等価回路で表した。 なお，各スタックに電解液を供給するための接続配管 
の抵抗は無視した。

著者らは，これまで，等価回路を用いてレドックス フロー型電池の効率推定を行ってきたが(15) (17), レド

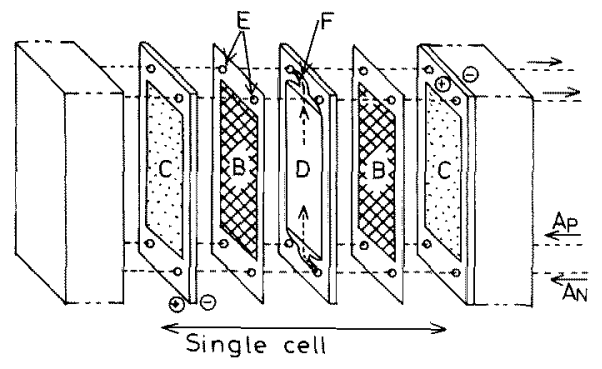

$A_{P}, A_{N}$ : Positive and negative electrolytes, B : A spacer mesh, $\mathrm{C}$ : Bipolar plate,,+- : Positive and negative electrodes, D: Plate with separator (Porous polyethylene membrane), $\mathrm{E}$ : Manifold, $\mathrm{F}$ : Slit

図 2 スタックの部品構成および電解液の流れ

Fig. 2. Components and bipolar assembly of a stack in a zinc/bromine battery.

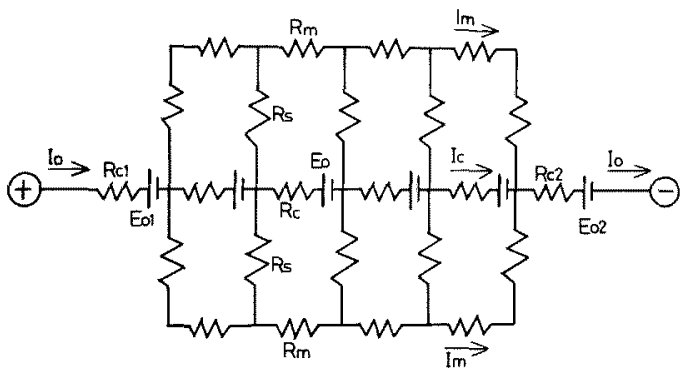

$R_{c}$ : The internal cell resistance, $R_{s}$ : The slit resistance, $R_{m}$ : The manifold resistance, $E_{0}$ : The electromotive force, $I_{0}$; The cell current, $I_{m}$ : The manifold current

図 3 西鉛一点素電池スタックの等価回路

Fig. 3. An equivalent circuit model for shunt current analysis on a stack of a zinc/ bromine battery.
ックスフロー型電池との相異点を考虑して，亜鉛一臭 素電池のためのモデルを作成した ${ }^{(3)(4)}$ 。亜鉛一悉素電 池では,（i）充電時に亜鉛が電析して負極にとどま り，放電時には覀鉛が溶解する，(ii）正極加ら拡散し てきた臬素と電析亜鉛とが反応して自己放電の原因と なる，などを考慮する必要がある。解析にあたり，

(i ) 負極における亜鉛電析, 溶解はセル内で一様であ る，(ii）自己放電などによる効率低下注充電状態によ り変わらない，などの仮定をおいた。

〈2・3〉計算方法およびパラメータ 亜鉛-臭素電 池ストリングの性能と信頼性に深くかかわるく2・1〉節 の(iii)，(v)，(vi)について検討するため，図3，図 4 の等価回路と以下に示すシミュレーションパラメー 夕を用いて，8時間率の定電力充放電の条件で充放電 シミュレーションを行った。なお，本研究でストリン グを対象としたのは，ストリングの充放電特性やス夕 ックなどの直並列時の課題を明らかにすることができ るので, 電池の充放電特性や充放電時の問題の把握が 容易となるからである。

充放電シミュレーションは，正負極液中の臭化亜鉛 の初期濃度と各サブモジュールのタンク液量を与えた 後, 各時間ステップごとに, 図 5 に示すようにストり ングの充放電電流值 $\left(I_{0}\right)$ を与えて，等価回路の各， 一ドの電位分布を求めた。このとき，各ノードの電位

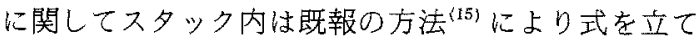
て, スタックの並列接続点では，例えば以下のように式 を組み立てて繰返し法により各ノードの電位を解いた。

$$
\sum_{j=1}^{N_{s t}} \frac{\left\{V_{s 1}(k)-V_{c}(2, j, k)-E_{o 1}(j, k)\right\}}{\left\{R_{c}(1, j, k)\right\}}=I_{0}
$$

ここに, $V_{s 1}, V_{c}, N_{s t}$ :それぞれ図 4 の等 価回路のスタッタ並列接続点の電位, 単電池

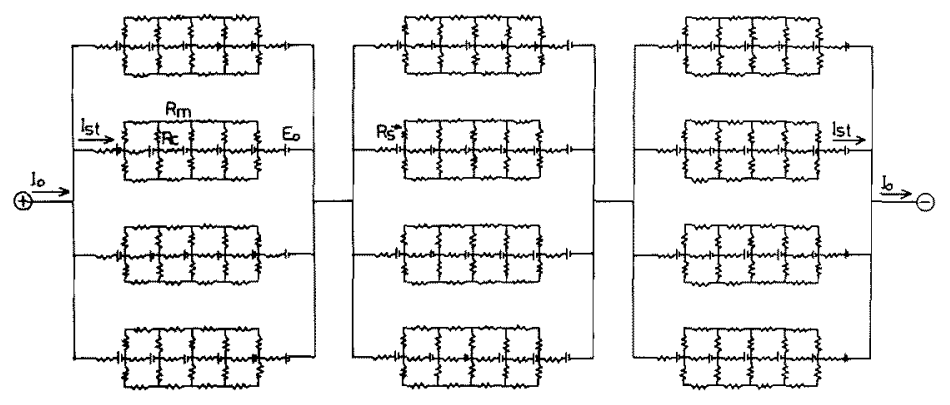

$R_{c}, R_{s}, R_{m}, E_{0}, I_{0}$ and same as those in Fig. 3. $I_{s t}:$ The stack current

図 $41 \mathrm{MW}$ 級西鉛一臭素電池ストリングの等価回路

Fig. 4. An equivalent circuit model for shunt current analysis on a string of the $1 \mathrm{MW}$ scale zinc/bromine battery. 
の正極側のノードの電位，スタックの並列接 続数, $i, j, k$ :図 40 等価回路の左加 $b k$ 番目の, サブモジュールの上から $j$ 番目の,

スタックの左加ら $i$ 番目の単電池

求められた電位分布と回路要素の值加ら等価回路の 電流分布を求めた。各単電池を流れる電流より, 各単 電池の負極に電析または残留する総亜鉛量 $\left(W_{z n}\right)$ を 以下の式より求めた。

充電時 $\left(t=0 \rightarrow t_{c}\right)$

$$
W_{z n}=\int_{0}^{t} \frac{\sum_{i, j, k} I_{c c}(i, j, k) \eta_{F c}(i, j, k)}{n F} d t \cdots
$$

放電時 $\left(t=t_{c} \rightarrow t_{d}\right)$

$$
\begin{aligned}
W_{z n}= & \int_{0}^{t c} \frac{\sum_{i, j, k} I_{c c}(i, j, k) \eta_{F C}(i, j, k)}{n F} d t \\
& -\int_{t c}^{t} \frac{\left(\sum_{i, j, k} I_{c D}(i, j, k) / \eta_{F D}(i, j, k)\right)}{n F} d t
\end{aligned}
$$

ここに, n, F, tc $t_{D}-t_{c}, I_{c}:$ そぞれイ オン荷数, ファラデー定数, 充電時間, 放電 時間, 单電池に流れる電流, $\eta_{F}$ : 単電池の 電流効率に関するパラメータであり，正極か らセパレータ(図2のD)を通して拡散して きた臭素と電析垔鉛との自己放電反応などに よる効率低下， $\eta_{F} や I_{c} に$ 添えた $C, D ：$ そ れぞれ充電時, 放電時, $\sum_{i, j, k}:$ サブモジュー ル内の単電池の総和

上記の計算にあたり，各充電状態での回路要素の值 は，50kW 級モジュールの電流-電圧特性 ${ }^{(3)(4)}$ や導電 率の測定結果 ${ }^{(20)} も と に$ をめた下の式(19)を用い

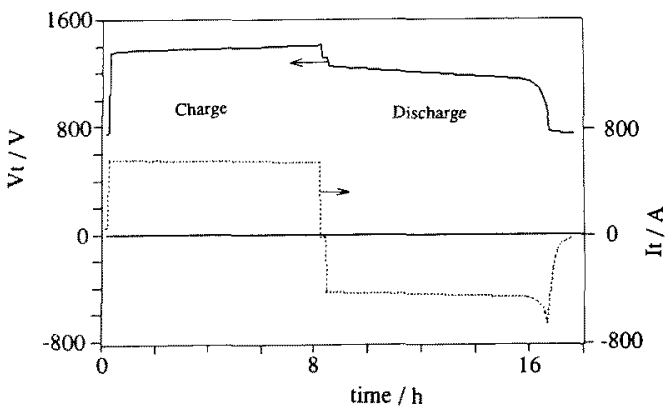

図 5 亜鉛-臭素電池ストリングの充放電 電流, 電圧

Fig. 5. Terminal voltage and current of a string of the IMW scale zinc/bromine battery during charging and discharging with constant power.
た。これらの回路要素值を用いたのは，50 kW 級モ ジュールと $1 \mathrm{MW}$ 級ストリングを構成する単電池, スタックの構造と電池構成材料がほとんど同じである からである。

$$
\begin{aligned}
\sigma_{N}= & 0.354-0.228(1-S O C) \\
& +0.0201(1-S O C)^{2} \cdots \cdots \cdots \cdots \cdots \cdots(4) \\
\sigma_{P}= & 0.171-0.0317(S O C)+0.0228(S O C)^{2}
\end{aligned}
$$

$$
S O C=1-\left[\mathrm{Zn}^{2+}\right] /\left[\mathrm{Zn}^{2+}\right]_{t=0}
$$

$E_{0}=1.72+0.107(S O C)+0.0113(S O C)^{2}$

$$
R_{c}=R_{\text {sol }}+R_{\text {rct }}
$$

$R_{\text {rct }}=0.00362+0.00105(S O C)+6.81$

$$
\times 10^{-6}(S O C)^{2}
$$

$$
\begin{aligned}
R_{r c t}= & \{0.00332-0.000818(S O C)+2.21 \\
& \left.\times 10^{-4}(S O C)^{2}\right\} \times\left\{1+f(1-S O C)^{m}\right\}
\end{aligned}
$$

$f=0.37 /(1-0.1209)^{m}$

$こ こ に, \sigma_{P}, \sigma_{N}, S O C,\left[\mathrm{Zn}^{2+}\right], R_{s o l}, R_{r c t}:$ それぞれ正極液の導電率, 負極液の導電率, 充電状態, 負極液中の亜鉛イオンの濃度, 七 儿溶液抵抗, 反応抵抗, $f, m:$ 放電末期の 開路電圧の增加に関連するパラメー夕 $(m=$ $7 \sim 12, f=0.9 \sim 1.7)$

以上のようにして求めた等価回路要素の基準值 ${ }^{(19)}$ を 表 2 に示す。

$\langle 2 \cdot 1\rangle$ 節の(iii)のスタック内単電池直列接続数 $\left(N_{c l}\right)$ とサブモジュールの直列接続数 $\left(N_{s b}\right)$ の影響 を検討するときには $N_{s b} \times N_{c l}=84$ になるように $N_{s b}$ と $N_{c l}$ を変化させた。

$〈 2 ・ 1\rangle$ 節の ( v ) の各スタックの電流-電圧特性と, ス タック内の各単電池の電流効率に関するパラメー 夕 $\left(\eta_{F}\right)$ と内部抵抗 $\left(R_{c}\right)$ のばらつきの影響を検討する

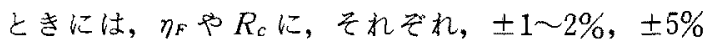
のばらつきを乱数を用いて与えた。その一例として， $\eta_{F}$ のばらつきの例を図 6 に示した。なお，スタック

表 2 充放電シミュレーションに用いた等価回路

\section{要素値 ${ }^{(19)}$}

Table 2. The standard values ${ }^{(19)}$ of the elements of an equivalent circuit model.

\begin{tabular}{l|l}
\hline & standard values \\
\hline Internal cell resistance & $0.004 \sim 0.01 \Omega$ \\
Manifold resistance & $0.4 \sim 0.6 \Omega$ \\
Slit resistance & $1.500 \sim 2,000 \Omega$ \\
Open circuit voltage & $1.6 \sim 1.9 \mathrm{~V}$ \\
\hline
\end{tabular}




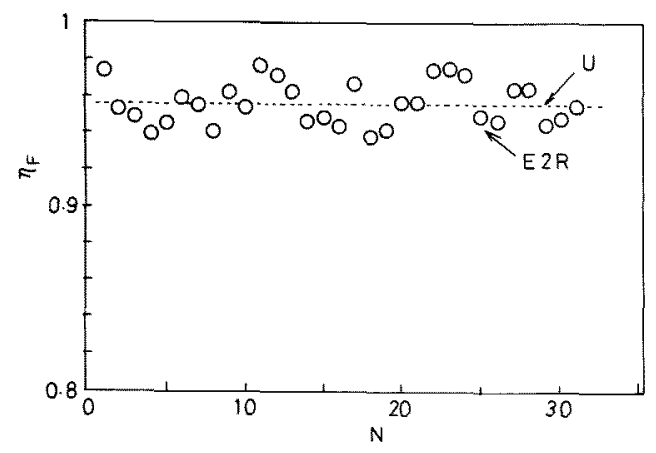

Symbol $U$ represents the standard values of $\eta_{F}$

図 6 充放電シミュレーションに用いた スタック内の単電池の $\eta_{F}$ 值

Fig. 6. The fluctuation of $\eta_{F}$ of the cells in a stack for the charge and discharge simulation.

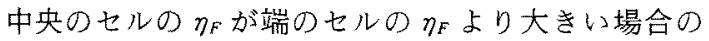
検討毛行った。

〈2・1〉節の(vi)のサブモジュール内の各スタックの 充放電効率や内部抵抗のばらつきの影響を検討すると きには，スタックごとに $R_{c} や \eta_{F}$ 基準值 ${ }^{(19)}$ の $1 \sim 1.75$ 倍，1倍〜0.85 倍と変化させた。

\section{3. 結果および考察}

〈3・1〉 スタック内電流分布と亜鉛電析分布 ${ }^{(19)}$

$50 \mathrm{~kW}$ 級垔鉛一臭素電池モジュール内のスタックの 充放電時の電流分析の計算結果の一例を図 7(a), (b)に示す。このとき表 1 ，表 2 の值を用いて匴し， スタック内単電池特性のばらつきはないと仮定した。

図 7 に見られるように，充放電時に充電電流と放電 電流の向きが逆にもかかわらず，シャント電流は同じ 方向に流れ，しかもスタック中央部で最大になってい る。このため，単電池内を流れる電流（絶対値）は， 充電時にスタック中央部で最小になり，放電時にはス タック中央部で最大となる。このような電流分布が, 図 8 に示すようなスタック内の亜鉛電析, 溶解㼂の分 布の一因となる。

\section{〈3・2〉 スタック内笚電池特性ばらつきの影響}

図 3 の等価回路を用いて，例えばスタック内の単電 池の $\eta_{F} R_{c}$ が図 6 に示したようにランダムにばら ついている場合の充放電シミュレーションを行い, 単 電池当たりの残留西鉛量, 放電電圧の時間変化を求め た。その一例として放電電压の時間変化を図 9 に示す。

図9に見られるように，スタックの放電電圧に単電 池の $R_{c}$ のばらつきは影響を与えないが， 〜 $2 \%$ とばつくと単電池の端子電压は基準の場合よ

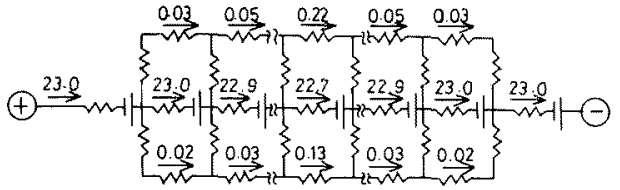

(a) Charge

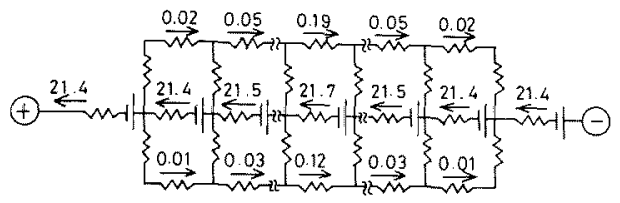

(b) Discharge

図 $750 \mathrm{~kW}$ 級覀鉛一臭素電池スタック心 電流分布

Fig. 7. Current distribution in a stack of the $50 \mathrm{~kW}$ scale $z$ inc/bromine battery at a SOC $50 \%$.

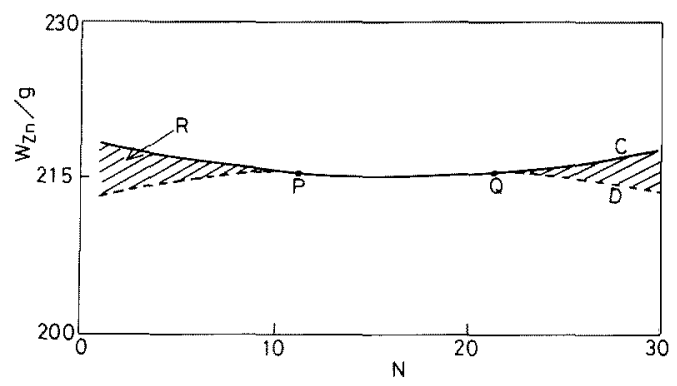

$C:$ at the end of charge, $D:$ at the end of discharge when average cell voltage reaches $1 \mathrm{~V}, R$ : Total amount of residual zinc metal

図 $850 \mathrm{~kW}$ 級亜鉛-臭素電池スタック内の 充電終了時の再鉛電析分布 (実線) 抢よび放電 終了時の亜鉛溶解量分布 (鎖線)

Fig, 8. Distribution of amounts of zinc metal deposited in the cells and dessolved from the cells in a stack.

り $230 \sim 480$ 秒速く急落する。この急落時刻は, 又夕 ック中央部の一つの単電池の電析亜鉛が完全溶解する 時刻に対応する。

既に述べたように：シャント電流により残留垔鉛量 はスタック中央部の活うが端の単電池より小さい。ス タック内の単電池の $\eta_{F}$ にばらつきがる場合, $\eta_{F}$ が 大きいほど残留亜鉛量が大きい。そこで，スタック中 央に $\eta_{F}$ の大きな単電池を接続すれ佂覀鉛が完全溶解 する時刻を遅らせることができるので，電池の放電時 間を伸ばすことができ，効率向上も期待できる。

なお，電析西鉛が完全溶解する時刻に関連する残留 


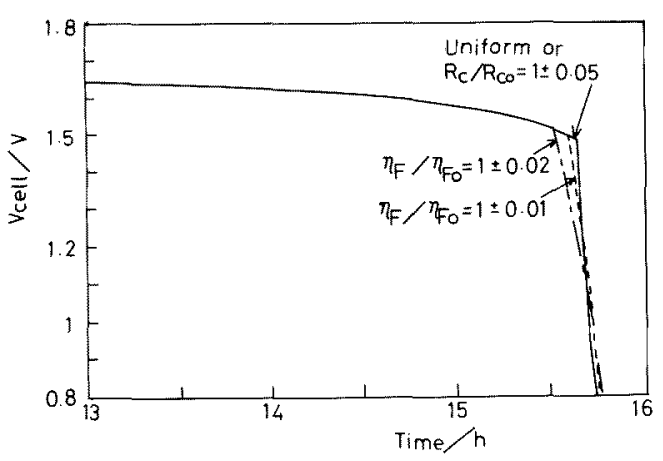

$\eta_{F} / \eta_{F \theta}=1 \pm 0.01\left(R_{C} / R_{C 0}=1\right), \quad \eta_{F} / \eta_{F O}=1 \pm 0.02\left(R_{c} / R_{C 0}=1\right)$ and $R_{C} / R_{C B}=1 \pm 0.05\left(\eta_{F} / \eta_{F 0}=1\right)$

図 9 ス夕ック内に直列接続されている 単電池门平均充放電電压

Fig. 9. The average terminal voltage of the cells connected in a stack.

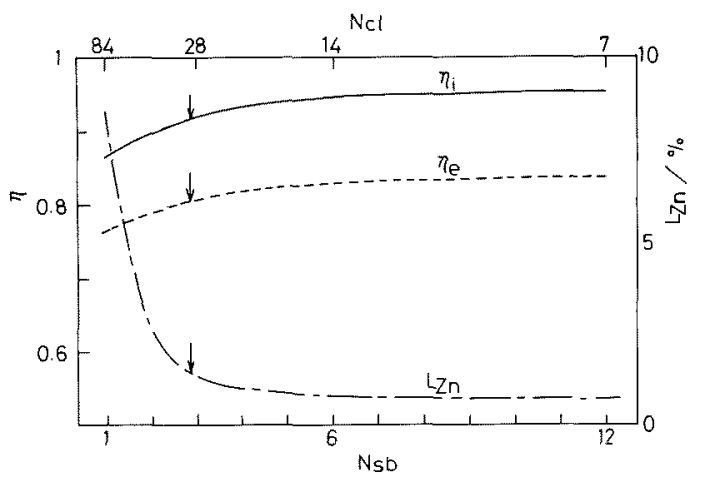

図 10 ストリングの充放電効率と 残留亜鉛損失

Fig. 10. The coulombic efficiencies $\left(\eta_{i}\right)$ and the energy efficies $\left(\eta_{e}\right)$ of a string, and the coulombic loss $\left(L_{z n}\right)$ due to the residual zinc metal of a string after the end of discharge.

亜鉛分布に内部抵抗がほとんど影響しないのは，表 2 に示したように，内部抵抗に対してスリット抵抗が十 分に大きいためである。すなわち，内部抵抗の值を変 化させても，等価回路の電流分布の変化が小さいから である。

〈3・3〉 $1 \mathrm{MW}$ 級ストリングのシミュレーション

(1)スタック分割の影響 図 10 にスタック内の 単電池の直列接続数を変えて構成したストリングを, 8 時間率で定電力充放電させたときの充放電効率, 残 留亜鉛損失の推定結果を示す。スタック内の単電池直 列接続数を大きくするほど（スタック分割数を小さく するほど）充放電効率が下がり，残留亜鉛損失が増加

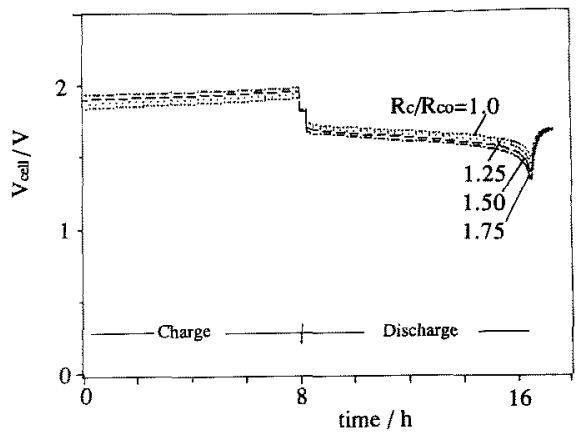

図 11 ストリングの端子電圧人の内部抵抗 のばらつき

Fig. 11. Time variation of the terminal voltage of a string.

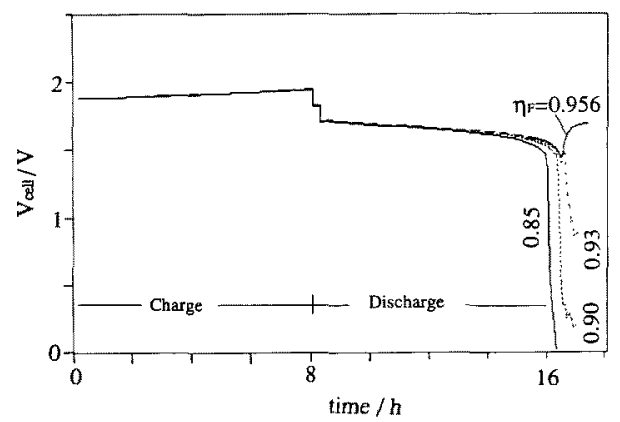

龱 12 ストリングの端子電圧への単電池の 電流効率のばらつきの影響

Fig. 12. Time variation of the terminal voltage of a string.

する結果を得た。スタック内単電池の直列接続数が増 加させるほど，残留亜鉛損失が増加するのはスタック 内のシャント電流分布が著しくなるため ${ }^{(18)}$ であり, 充放電効率が下がるのはシャント電流の平均值が大き くなる(16) ためである。図 10 より，スタックを分割す るほど有利と思われるが，スタック分割を大きくする と部品数が増加し信頼性や経済性の面で不利になるの で, 単電池直列接続数は $20 \sim 30$ が適当上思われる。

（2）スタック特性のばらつきの影響図 11, 図 12 に端子電圧の変化を示すが，それぞれ，各サブ モジュール内の単電池の $R_{C}$ や $\eta_{F}$ が基準值 ${ }^{(19)} の$ $1 \sim 1.75$ 倍, $1 \sim 0.85$ 倍である場合の結果である。上 記の結果を含め一連のシミュレーションを行った結 果, (i ) 端子電圧の急落す万時刻や放電終了時の残留 亜鉛に $R_{\mathrm{c}}$ はほとんど影響しないが， $\eta_{F}$ は影響する， (ii)従って端子電圧の急落時刻よりお抢上その $\eta_{F}$ を 推定することができる，(iii） $R_{c}$ は $1 \mathrm{MW}$ 級ストリン グの電圧効率に， $\eta_{F}$ は主に電流効率に影響する，な どの結果を得た。 


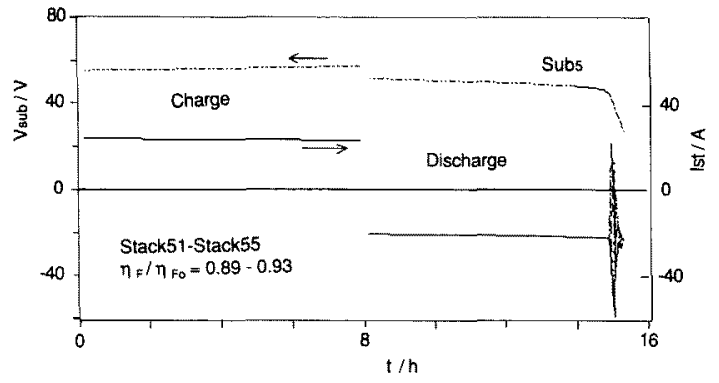

図 13 サブモジュール内の 5 個のスタック 電流の時間変化

Fig. 13. Time variation of the stack currents of the five stacks in the No. 5 submodule.

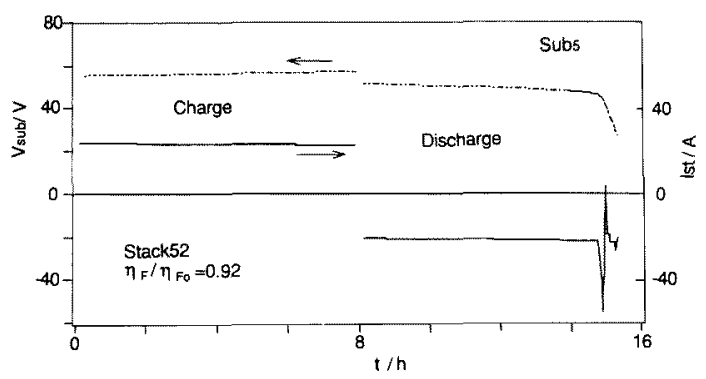

図 14 サブモジュール内のNo.2スタック の電流の時間変化

Fig. 14. Time variation of the stack current of the No. 2 stack in the No. 5 submodule.

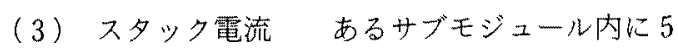
個並列接続されているスタックの $\eta_{F}$ が，基準值の 0.89〜0.93 倍にばらついているときのスタック電流 の時間変化を図 13 に示す。同図に見られるように, 放電末期を除いて，スタック電流の時間変化は小さ く，しかも互いに一致している。しかし放電末期に は,スタック電流は複雑に変化する結果を得た。また 図 14 に，あるスタックに流れる電流の時間変化を示 したが，スタック電流が振動する結果が得られた。以 上のような結果は実験的にも得られている(20)。

図 15 に放電末期の各スタック内の残留亚鉛分布の 一例を示す。単電池の電流効率のばらつきにより，ス タックごとにセル間の残留亜鉛分布が異なり，スタッ ク中央の単電池内の覀鉛が完全に溶解する時刻が， ス タックごとに異なる。そのために，図 13 のような結 果が得られたと考えられる。また，図 14 に示すよう なスタック電流が振動する結果が得られたのは，ある スタックに流れる電流が急変すると, スタック中央部 の単電池内の亜鉛の溶解速度も変わり, スタック間の 残留亜鉛量のバランスが変わり, 各スタックの開路電

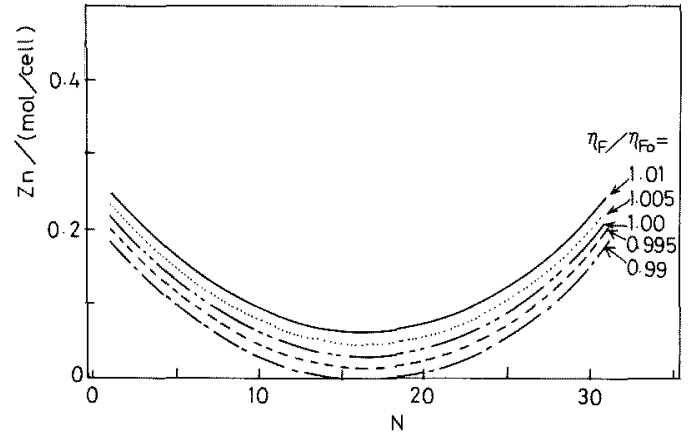

図 15 スタック内の単電池間の残留亚鉛分布 Fig. 15. An example of distribution of amounts of residual zinc metal in the five stacks in a submodule.

圧バランスが変化するためである。

\section{4. むす び}

亜鉛一臭素電池ストリングの等価回路を用いて充放 電シミュレーションを行ったが，明らかになったこと は,

（1） ストリングの等価回路モデルにより，シャン 卜電流損失, スタック電流, 端子電圧, 充放電効率, 亜鉛 電析・溶解分布などを予測することが可能になった。

（2）電力貯蔵用西鉛-臭素電池 ${ }^{(3) \sim(6)}$ では，スタッ ク内の単電池直列接続数は充放電効率, 放電停止後の 残留垔鉛量などにより，20３0が適当と思われる。

（3）ストリングを充放電させた場合，内部抵抗の ばらつきは放電時間や残留西鉛量には影響を与えない が，単電池の電流効率のばらつきは，放電末期のス夕 ック電流の急変に関連し，また放電時間，残留央鉛量， 充放電効率へ影響を与之る。

本研究の今後の課題は, $1 \mathrm{MW}$ 級要鉛-臭素電池の 充放電効率の試験データと予測值の比較である。ま た，電力貯蔵用の亚鉛一臭素電池の効率を更に向上さ せるためには，放電終了後に残留している亜鉛の完全 溶解過程を省略することであるが，その効果の推定の ためには，シミュレーションモデルの改良が必要であ る。

本研究は, ムーンライト計画, 新型電池電力貯蔵シ ステムの研究開発の一環として行われた。

(平成 4 年 11 月 27 日受付, 同 5 年 4 月 2 日再受付)

$$
\text { 文献 }
$$

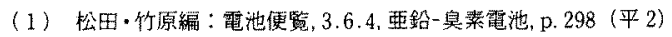
丸盖

（2）野崎・金子・小沢：「レドックス・フロ一型電池の開発」,電 気学会研凟, EDD-80-62, ESC-80-26, p. 43 (昭 55) 
(3) T. Fujii, K. Fushimi, T. Hashimoto, Y. Kumai, A. Hirota, H. Itoh, K. Jin-nai, M. Kanazashi, T. Hiramatsu \& S. Kondo: " $80 \mathrm{kWh}$ Zinc/Bromine Battery for Electric Power Storage", Proc. 22nd Intersoc Energy Conv. Eng. Conf., Vol. 1, p. 1045 (1987)

(4) T. Fujii, M. Igarashi, K. Fushimi, T. Hashimoto, Y. Kumai, A. Hirota, H. Itoh, K. Jin nai, M. Kanazashi, T. Hiramatsu \& T. Nakayama: "4 MWh Zinc/Bromine Battery for Electric Power Storage", Proc. 23rd ibid., Vol. 2, p. 335 (1988)

(5) T. Fujii, M. Igarashi, K. Fushimi, T. Hashimoto, A. Hirota, H. Itoh, K. Jin-nai, Y. Tagami, I. Kouzuma, Y. Sera \& T. Nakayama: "4MWh Zinc/Bromine Battery for Electric Power Storage", Proc. 24th ibid., Vol. 3, p. 1319 (1989)

(6) T. Fujii, M. Igarashi, K. Fushimi, T. Hashimoto, A. Hirota, H. Itoh, K. Jin-nai, T. Hashimoto, I. Kouzuma, Y. Sera \& T. Nakayama: "Zinc/Bromine Battery for Electric Power Storage", Proc. 25th ibid., Vol. 3, p. 136 (1990)

(7) A. Leo: "Status of Zinc-Bromine Battery Development at Energy Research Corporation", Proc. 24th ibid., Vol. 3, p. 1303 (1989)

(8) J. J. Bolstad \& R.C. Miles: "Development of the Zinc/ Bromine Battery at Jhonson Controls, Inc", Proc. 24th ibid., Vol. 3, p. 1311 (1989)

(9) J. P. Zagrodnik \& M. D. Eskra: "Zinc/Bromine Battery Development", Proc. 22nd. ibid., Vol. 3, p. 1039 (1989)

(10) H. Nakao, Y. Suzuki \& M. Okawa: "Zinc-Bromine Battery Development for Toyota EV30", Proc. the 9th Intern. Electric Vehicle Symposium, Toronto (1988)

(11) P. G. Grimes, R. J. Bellows \& M. Zahn: "Shunt Current Control in Electrochemical Systems Theoretical Analysis", R. E. White, Ed., "Electrochemical Cell Design", p. 259 (1984) Plenum Press Co., New York

（12）二又・高橋：「電気自動車用電池の開発状況, 5. 亜鉛-臭素 電池」, 大阪工試季報, 37, 240 (昭 61)

(13) T. I. Evans \& R. E. White: "A Review of Mathematical Modeling of the Zinc/Bromine Flow Cell and Battery", J. Electrochem. Soc., 134, No.11, 2725 (1987)

(14) J. V. Zee, R. E. White, P. G. Grimes \& R. J. Bellows: "A Simple. Model of Exxon's $\mathrm{Zn} / \mathrm{Br}_{2}$ Battery" R.E. White, Ed., "Electrochemical Cell Design", p. 259 (1984) Plenum Press Co., New York

（15） 金成・野崎・小沢：「1 kW 級レドックス・フロー型電池スタ ックのシャント電流解析了, DENKI KAGAKU, 55, No. 3, 251(昭 62)

(16) K. Kanari, K. Nozaki \& T. Ozawa: "Numerical Analysis on Shunt Current and Pumping Loss in a Redox-Flow Cell System", AIChE Symposium Series, "Electrochemical Applications", R.E. White et al. Ed., No. 254, 83, 104 (1987)

（17）金成・野崎・小沢：「1 kW 級レドックス・フロー型二次電池 のシャント電流解析」, DENKI KAGAKI、57, No.6, 517 (平元)

（18）金成・野崎・橋本・藤井：「亜鉛-臭素電池のシャント電流解 析」, 同上, $\mathbf{5 9}, 237$ (平 3 )

(19) K. Kanari, K. Nozaki \& H. Kaneko: "Numerical Analysis on Shunt Current in Flow Batteries", Proc. 25th Intersoc. Energy Conv. Eng. Conf., Vol. 3, 326 (1990)

(20) 藤井：私信
ギー基礎部エネルギー材料研究室主任研究官。工学博士。 主として, 蓄熱技術, 宇宙エネルギー技術, フロー型電 池, 分散電源用高性能電池などの研究に従事。

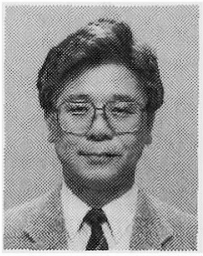

\section{野 崎健（正員）}

昭和 18 年 6 月 11 日生。 43 年 3 月東 京大学大学院工業化学専攻修士課程修 了。同年 4 月電気試験所（現，電子技術 総合研究所）入所。現在，電子技術総合 研究所エネルギー部高温エネルギー研究室主任研究官。主 として, 新型電池, 燃料電池などの電気化学的エネルギー 技術の研究に従事。6 60 年市村賞受賞。

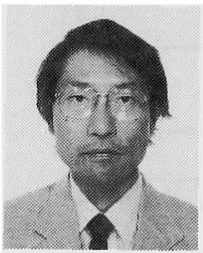

神本 正行 (正員)

昭和 23 年 2 月 8 日生。 50 年 3 月東京 大学大学院博士課程修了。アメリカ・ Northwestern 大学材料科学科客員研究 員を経て，52 年 4 月電子技術総合研究 所入所。現在，電子技術総合研究所エネルギー基礎部主任 研究官。主として，エネルギー材料，蓄熱技術，宇宙エネ ルギー技術，熱纷析および熱物性測定などの研究に従事。

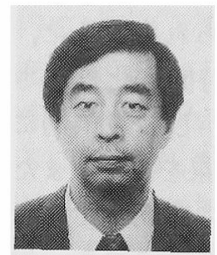

\section{橋 本 敬 史 (非会員)}

昭和 27 年 2 月 10 日生。 49 年 3 月東 京理科大学大学院理工学部物理科卒業。 同年 4 月 (株)明電舎入社。現在，(株)明 電舎研究開発総本部総合研究所開発第二 部担当課長。主として, 電力貯蔵用亜鉛一臭素電池の開発 に従事。

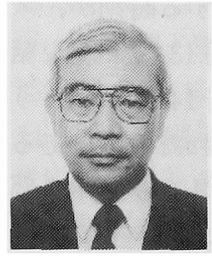

\section{藤 井 利 宣 (正員)}

昭和 17 年 5 月 19 日生。 44 年 3 月東 京都立大学大学院修士課程修了。同年 4 月 (株) 明電舎入社。現在, (株)明電舎研 究開発総本部総合研究所技師長。主とし て, 電力貯蔵用亜鉛-臭素電池の開発に従事。 